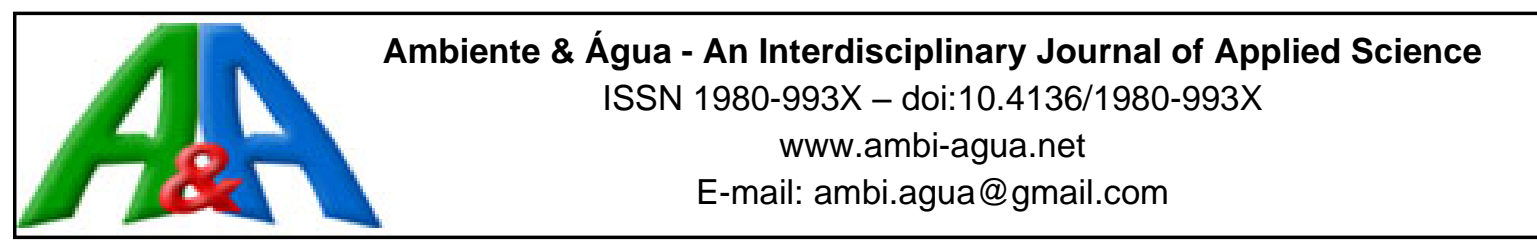

\title{
Adequacy of methodologies for determining SCS / CN in a watershed with characteristics of the Pampa biome
}

\author{
ARTICLES doi:10.4136/ambi-agua.2715 \\ Received: 01 Mar. 2021; Accepted: 24 May 2021
}

\begin{abstract}
Zandra Almeida da Cunha ${ }^{1 *}$; Samuel Beskow1(iD; Maíra Martim de Moura1 ${ }^{1 D}$; Tamara Leitzke Caldeira Beskow ${ }^{1}$ (D); Carlos Rogério de Mello ${ }^{2}$ iD

${ }^{1}$ Centro de Desenvolvimento Tecnológico. Universidade Federal de Pelotas (UFPel), Rua Gomes Carneiro, $\mathrm{n}^{\circ} 1$, CEP: 96010-610, Pelotas, RS, Brazil. E-mail: samuelbeskow@gmail.com, martimdemoura@gmail.com, tamaraleitzkecaldeira@gmail.com

${ }^{2}$ Departamento de Recursos Hídricos. Universidade Federal de Lavras (UFLA), Aquenta Sol, s/n, CEP: 37200-900, Lavras, MG, Brazil. E-mail: crmello@ufla.br

*Corresponding author. E-mail: zandraacunha@gmail.com
\end{abstract}

\begin{abstract}
The Soil Conservation Service Curve Number Model is a conceptual model intended for estimating effective rainfall (ER). This model is grounded in a parameter - referred to as Curve Number $(\mathrm{CN})$, which is determined from information on the characteristics of the watershed. The Standard Method (M1) for determining the $\mathrm{CN}$ is based on soil and land-use tables; however, some authors have proposed alternative methodologies for defining the $\mathrm{CN}$ value from monitored rainfall-runoff events, such as those described by Hawkins (1993) (M2), Soulis and Valiantzas (2012) (M3), and Soulis and Valiantzas (2013) (M4). The objective of this study was to evaluate the impact of using these methods for determination of the $\mathrm{CN}$ parameter on the estimation of ER, taking as reference forty rainfall-runoff events monitored between 2015 and 2018 in the Cadeia River Watershed, which has characteristics of the Pampa biome. The different methods assessed for definition of the $\mathrm{CN}$ parameter resulted in contrasting performances with respect to the estimation of ER for CRW, as the following findings: i) M1 gave ER values with little reliability, mainly due to the classification of antecedent moisture content classes; ii) M3 provided the best results in determining ER, followed by M2; and iii) the ER values estimated according to M4 differed from those observed, mainly for events with lower rainfall depths.
\end{abstract}

Keywords: effective rainfall, extreme events, hydrological modeling.

\section{Adequação de metodologias para determinação de SCS / CN em uma bacia hidrográfica com características do bioma Pampa}

\section{RESUMO}

O Modelo do Número da Curva do Serviço de Conservação do Solo é um modelo conceitual destinado a estimar a precipitação efetiva (ER). Esse modelo está embasado em um parâmetro - denominado Curve Number $(\mathrm{CN})$, que é determinado a partir de informações sobre as características da bacia hidrográfica. O Método Padrão (M1) para determinar o CN é baseado em tabelas de solo e uso da terra, no entanto, alguns autores propuseram metodologias alternativas para definir o valor de $\mathrm{CN}$ de eventos monitorados de chuva-escoamento, como 
aqueles descritos por Hawkins (1993) (M2), Soulis e Valiantzas (2012) (M3) e Soulis e Valiantzas (2013) (M4). O objetivo deste trabalho foi avaliar o impacto da utilização desses métodos para determinação do parâmetro $\mathrm{CN}$ na estimativa da ER, tomando como referência quarenta eventos pluviométricos monitorados entre 2015 e 2018 na bacia do rio Cadeia, que possui características de Bioma Pampa. Os diferentes métodos avaliados para definição do parâmetro $\mathrm{CN}$ resultaram em desempenhos contrastantes no que diz respeito à estimativa de ER para CRW, como os seguintes achados: i) M1 deu valores de ER com pouca confiabilidade, principalmente devido à classificação das classes de teor de umidade antecedentes; ii) M3 apresentou os melhores resultados na determinação de ER, seguido de M2; e iii) os valores de ER estimados de acordo com o M4 diferiram dos observados, principalmente para eventos com menores profundidades de chuva.

Palavras-chave: chuva efetiva, eventos extremos, modelagem hidrológica.

\section{INTRODUCTION}

Knowledge of the hydrological cycle is essential for the adequate management of water resources. In this sense, direct surface runoff (DSR) is one of the most important components of the hydrological cycle, especially when considering practical issues involving hydrological engineering (Alves et al., 2019).

The generation of DSR is dependent on variables associated with the rainfall event, such as its intensity and duration, as well as characteristics of the watershed, e.g. soil classes, land uses, and topography (Elhakeem and Papanicolaou, 2009; Lal et al., 2016). Thus, according to Araújo Neto et al. (2012) and Soulis and Valiantzas (2013), the use of hydrological models to estimate DSR in watersheds is necessary.

Among the existing models, the Soil Conservation Service Curve Number (SCS/CN) (NRCS, 1986) is the simplest conceptual model for estimation of DSR (Ajmal and Kim, 2014), which is numerically equal to effective rainfall (ER). According to Ponce and Hawkins (1996), the SCS/CN model aims to estimate the DSR volume yielded during a rainfall event based on a parameter known as the Curve Number $(\mathrm{CN})$. Although SCS/CN model has been designed for agricultural watersheds in the United States, the model has been widely applied in locations with different edaphoclimatic characteristics (Ajmal and Kim, 2014; Oliveira et al., 2016; Walega et al., 2015; Endale et al., 2015; D'Asaro et al., 2014; Deshmukh et al., 2013). Given its simplicity, the SCS/CN model and its adaptations are often coupled in more complex hydrological models, e.g., models originated from the Unit Hydrograph (HU) theory, the Soil and Water Assessment Tool (SWAT) (Arnold et al., 1998) and the Lavras Simulation of Hydrology (LASH) (Beskow et al., 2011).

The application of the SCS/CN model is greatly impacted by the relationship established between the initial rainfall abstraction $\left(\mathrm{I}_{\mathrm{a}}\right)$ and the maximum potential for water infiltration in the soil (S), expressed by the coefficient of initial rainfall abstractions $(\lambda)$. Ponce and Hawkins (1996) reported that $\lambda$ depends on the relief, vegetation, and climatological characteristics of the watershed. Due to the direct influence of $\lambda$ on the estimates of ER, the definition of its value has been discussed by several authors (Alves et al., 2019; Mishra and Singh., 2006; Valle Junior et al., 2019).

It is known that the SCS/CN model requires the $\mathrm{CN}$ parameter, which can be calculated for each rainfall-runoff event by using data on ER and $\mathrm{I}_{\mathrm{a}}$, as in the study by Alves et al. (2019). However, when there are limitations or absence of observed data, $\mathrm{CN}$ is determined based on the tabulated $\mathrm{CN}$ values included in the method documentation for various soil/land use complexes, without considering the characteristics of the rainfall event. Furthermore, the determination of this parameter is subjective when considering the effect of antecedent soil 
moisture content conditions (Soulis and Valiantzas, 2012).

Therefore, the practicality of assigning a constant CN parameter for the estimation of DSR, based only on physical characteristics of the watershed, is subjective and susceptible to errors. This is expected to occur mainly when applied to watersheds with different physiographic characteristics from those used for the development of the SCS/CN model, such as the watershed assessed in this study, situated in the Pampa biome in Southern Brazil. According to Lupatini et al. (2013), the Pampa biome covers part of Southern Brazil, has distinct characteristics of vegetation, climate, and soil classes, and is characterized by a great plant and animal diversity.

According to Soulis (2018) in cases of watersheds with different characteristics, it is more appropriate to estimate the $\mathrm{CN}$ values based on the analysis of actual hydrological observations, comparing the hydrological response in different conditions. In this context, several methods have been developed and recommended for the determination of the $\mathrm{CN}$ parameter using measured rainfall-runoff data, considering variables of influence on the generation of DSD, e.g., Hawkins (1993), Soulis and Valiantzas (2012), and Soulis and Valiantzas (2013). Nevertheless, little is known so far about the coherence of the $\mathrm{CN}$ parameter derived from these methods with the reality of each watershed, thereby making it necessary to compare the results of these methods with the values obtained from observed rainfall-runoff data.

The aforementioned methods have been frequently applied for modelling of rainfall events with high intensities and short durations (less than one day), that is, in consonance with the original development of the SCS/CN model (Ajmal et al., 2015; Mishra et al., 2008; Walega et al., 2015; Endale et al., 2015; D'Asaro et al., 2014; Deshmukh et al., 2013). Mishra et al. (2008) stress that the generation of DSR in a watershed is also dependent on the rainfall duration, as losses by infiltration and evapotranspiration are directly related to the time the water remains on the surface of the watershed. Consequently, it is necessary to investigate the application of the SCS/CN model for rainfall events with long durations, verifying the variability of the $\mathrm{CN}$ parameter over the duration of the event (Žlábek et al., 2012; Mishra et al., 2008).

In view of the above, the objective of this study was to evaluate the impact of using different methodological proposals for determination of the $\mathrm{CN}$ parameter on the estimation of ER according the SCS/CN model, taking as reference a watershed with typical characteristics of the Pampa biome and with rainfall durations lasting more than one day.

\section{MATERIAL AND METHODS}

\subsection{Characterization of the study area}

The Cadeia River Watershed (CRW) was evaluated in this study. CRW is located in the south of Rio Grande do Sul (Figure 1), has a drainage area of $121.3 \mathrm{~km}^{2}$ and is one of the main sub-watersheds of the Pelotas River Watershed (PRW). The Research Group on Hydrology and Hydrological Modeling in Watersheds is responsible for a hydrological monitoring network installed in the PRW (Figure 1). In this work, rainfall data were obtained from seven recording rain gauges and streamflow data were acquired from 1 hydrological gauging station (Figure 1a).

CRW is inserted in the Pampa biome, in the southeast region of Rio Grande do Sul State/Brazil. This region is characterized by a subtropical climate with great influence from polar systems (Kuplich et al., 2018). According to the Köppen classification, the climate of the region is characterized as $\mathrm{Cfa}$, with an average temperature of the warmest month exceeding $22^{\circ} \mathrm{C}$ and well-distributed monthly rainfall (Alvares et al., 2014). The average annual rainfall depth in CRW is $1,367 \mathrm{~mm}$ (Steinmetz et al., 2019).

The Pampa biome is characterized by typical vegetation, such as natural grassland and sparse formations of shrubs and trees (Overbeck et al., 2007), and by a wide variety of soil types (Lupatini et al., 2013). Information on the soil classes existing in the CRW were extracted 
from the soil map of the Conselho Regional de Desenvolvimento da Região Sul (COREDESUL), prepared by the Laboratório de Planejamento Ambiental of the Empresa Brasileira de Pesquisa Agropecuária (EMBRAPA/Clima Temperado) taking as reference the study conducted by Cunha et al. (2006). The study area is characterized by the presence of Ultisols, according to Soil Taxonomy classification (Soil Survey Staff, 2014). This corresponds to the Yellow Argisol (78.7\%), Red Argisol (14.7\%) and Grayish Brown Argisol (6.6\%) (Figure 1b), according to the Brazilian Soil Classification System - SiBCS (Santos et al., 2018). According to Beskow et al. (2018), the land-use classes identified in CRW are forest (31.0\%), grassland (30.0\%), bare soil (25.0\%), pasture (13.9\%), and water body (0.1\%) (Figure 1c).

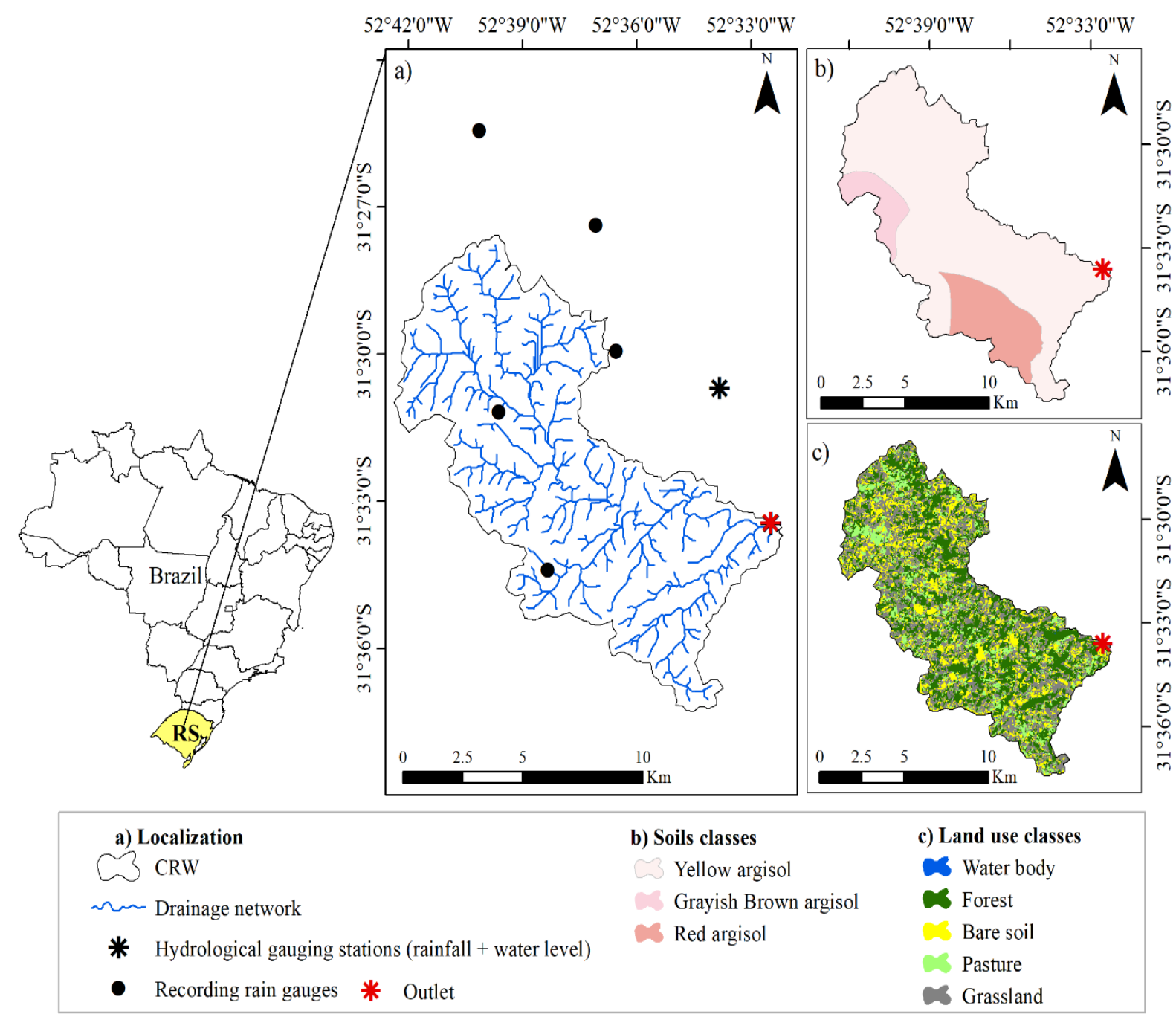

Figure 1. a) Location of the CRW in the Rio Grande do Sul State and Brazil, as well as the stations of the monitoring network used in this study; (b) soil classes and (c) land uses found in CRW.

\subsection{Soil Conservation Service/Curve Number Model (SCS/CN)}

The present study was carried out using the SCS/CN Model developed by the Soil Conservation Service (NRCS, 1986) of the United States Department of Agriculture (USDA), which has been widely used for estimating ER in watersheds. According to Cao et al. (2011), this model considers that the ER resulting from a given rainfall event is a function of both rainfall depth $\left(R_{\text {total }}\right)$ and initial abstraction $\left(\mathrm{I}_{\mathrm{a}}\right)$. The $\mathrm{I}_{\mathrm{a}}$ is associated with the initial losses that occur due to the processes of interception by land cover, infiltration, evaporation, and water retention by depressions of the terrain. SCS/CN is represented by Equations 1 and 2 and assumes there is a relationship between $I_{a}$ and $S$ (maximum potential retention) (Equation 3 ) 
expressed by $\lambda$ (initial abstraction ratio) (NRCS, 1986). On investigating the $I_{a}$ values in agricultural watersheds in the United States, (NRCS, 1986) stated that the values of $I_{a}$ corresponded to $20 \%$ of $\mathrm{S}$ on average, in other words, $\lambda$ was equal to 0.2 .

$$
\begin{aligned}
& E R=\frac{\left(R_{\text {total }}-I_{a}\right)^{2}}{\left(R_{\text {total }}-I a\right)+S} \\
& S=\frac{25400}{C N}-254 \\
& I_{a}=K \cdot S
\end{aligned}
$$

Where: ER is the effective rainfall $(\mathrm{mm}), \mathrm{R}_{\text {total }}$ refers to the total rainfall depth $(\mathrm{mm}), \mathrm{I}_{\mathrm{a}}$ is the initial abstraction $(\mathrm{mm}), \mathrm{S}$ corresponds to the maximum potential for water retention in the soil (mm), and $\mathrm{CN}$ is the Curve Number parameter.

\subsection{Methods for determining the $\mathrm{CN}$ parameter}

The values of the $\mathrm{CN}$ parameter were defined according to four methods analyzed in this study to evaluate SCS/CN model taking as reference rainfall-runoff events observed in the CRW: i) estimating CN values from tabulated values (NRSCS, 1986) based on the physiographic characteristics of the watershed (treating the water as ungauged) (M1), combined with the physiographic characteristics of the watershed under analysis; ii) asymptotic $\mathrm{CN}$ (Hawkins, 1993) (M2); iii) Two CN (Soulis and Valiantzas, 2012) (M3); and iv) Heterogeneous CN (Soulis and Valiantzas, 2013) (M4). For comparative purposes, the CN for each rainfallrunoff event was also calculated and considered as observed $\mathrm{CN}\left(\mathrm{CN}_{\mathrm{obs}}\right)$.

\subsubsection{Standard tables for CN (NRCS, 1986) - (M1)}

The soils were classified in accordance with the hydrologic soil groups established by the SCS/CN model, following the classification proposed by Sartori et al. (2005) for Brazilian soils. Information on the potential of a specific soil type for generation of DSR, e.g., texture, depth and transition between horizons, was used for the aforementioned classification (Sartori et al., 2005). Therefore, the Red Argisol was classified as Group B, as it is characterized by a moderate depth and infiltration rate, a moderate to good drainage, and a moderately fine to moderately coarse texture. The Yellow Argisol was classified as Group $\mathrm{C}$ due to its low infiltration rate, fine texture, and layers that hinder the vertical movement of water. Finally, the Grayish Brown Argisol was defined as Group D because it has a high potential for DSR generation, with a very low infiltration rate.

After the classification of soil types, they were merged with the land-use classes found in the watershed in order to determine the $\mathrm{CN}$ value corresponding to each combination, considering the intermediate conditions of antecedent moisture content (AMC $\mathrm{AI}_{\mathrm{II}}$. The $\mathrm{CN}$ values $\left(\mathrm{CN}_{\mathrm{II}}\right)$ used in this study for the different combinations of hydrologic soil groups and land-use classes are presented in Table 1. Afterwards, the $\mathrm{CN}_{\text {II }}$ values were spatialized in the watershed, weighted by the areas of occurrence of each value, to obtain an average $\mathrm{CN}_{\text {II value }}$.

However, according to the method, the actual antecedent moisture content is related to the rainfall depth that occurred in the last five days $\left(\mathrm{R}_{5}\right)$, so it must be evaluated for each event. Following the framework proposed by ASCE (1996) referred to as Antecedent Moisture Content (AMC), the $\mathrm{CN}$ values were grouped into three conditions: AMC I (dry soil and $\mathrm{R}_{5}$ up to $35 \mathrm{~mm}$ ), AMC II (moist soil corresponding to field capacity and $\mathrm{R}_{5}$ between 35 and 52.5 $\mathrm{mm}$ ) and AMC III (very moist soil and $\mathrm{R}_{5}$ greater than $52.5 \mathrm{~mm}$ ). In this sense, the average $\mathrm{CN}_{\text {II }}$ value was corrected for the AMC class according to the characteristics of each rainfall event assessed in this study, using Equations 4 and 5, as presented by Chow et al. (1988). 
Table 1. $\mathrm{CN}_{\text {II }}$ values for each combination identified in the CRW of land-use class and hydrologic soil group.

\begin{tabular}{ccccc}
\hline \multirow{2}{*}{ Land use in the CRW } & Reference* & \multicolumn{3}{c}{ Hydrologic soil group } \\
\cline { 3 - 5 } & Water & 100 & 100 & 100 \\
\hline Water body & Regular Plantations - in straight rows & 75 & 83 & 87 \\
Pasture & Permanent fields - normal & 58 & 71 & 78 \\
Grassland & Forests - normal & 60 & 70 & 76 \\
Forest & Plowed soil - in straight rows & 80 & 87 & 90 \\
Bare soil & & & & \\
\hline
\end{tabular}

* Adapted from Huffman et al. (2011) and NRCS (1986).

$C N_{I}=\frac{4,2 \cdot C N_{I I}}{10-0,058 \cdot C N_{I I}}$

$C N_{I I I}=\frac{23 \cdot C N_{I I}}{10+0,13 \cdot C N_{I I}}$

Where: $\mathrm{CN}_{\mathrm{I}}$ and $\mathrm{CN}_{\mathrm{III}}$ are the corrected $\mathrm{CN}$ values corresponding to the classes $\mathrm{AMC}$ I and AMC III, respectively.

\subsubsection{Asymptotic Determination Method of runoff Curve Numbers (Hawkins, 1993) - (M2)}

The M2 was developed by Hawkins (1993) and allows the determination of CN values from observed rainfall-runoff events, using the frequency matching concept. First, the observed values of $R_{\text {total }}$ and ER were independently classified in decreasing order, forming $R_{\text {total }}$ :ER pairs with equal return periods (Hawkins, 1993). Subsequently, the CN values were determined for each $R_{\text {total }}$ ER pair found using Equation 6 (Hawkins 1993).

$$
\mathrm{CN}=\frac{25400}{\frac{\mathrm{R}_{\text {total }}}{\lambda}+\left(\frac{(1-\lambda) \mathrm{ER}-\sqrt{(1-\lambda)^{2} \mathrm{ER}^{2}+4 \lambda \mathrm{R}_{\text {total }} \mathrm{ER}}}{2 \lambda^{2}}\right)+254}
$$

Where: ER is the effective rainfall ( $\mathrm{mm}), \mathrm{R}_{\text {total }}$ refers to the rainfall depth $(\mathrm{mm}), \lambda$ is the initial rainfall abstraction ratio, equal to 0.2 , and $\mathrm{CN}$ corresponds to the Curve Number.

The $\mathrm{CN}$ values determined in accordance with Equation 6 were analyzed in order to classify the behavior of CRW with respect to the observed $\mathrm{CN}$ values and $\mathrm{R}_{\text {total }}$. The following behaviors can be identified (Hawkins 1993): i) complacent behavior, when the calculated values of CN constantly decrease as $\mathrm{R}_{\text {total }}$ increases, without any observable tendency to reach a stable value; ii) standard behavior, if the lowest $\mathrm{R}_{\text {total }}$ values result in the highest calculated $\mathrm{CN}$ values, tending to decrease progressively as rainfall increases, approaching a constant $\mathrm{CN}$ value; and iii) violent behavior, in which the calculated $\mathrm{CN}$ value has a constant value for all $\mathrm{R}_{\text {total }}$ values, except for those of small magnitude where the $\mathrm{CN}$ values increase sharply.

Hawkins (1993) proposed Equations 7 and 8 to adjust the $\mathrm{CN}$ value as a function of $\mathrm{R}_{\text {total }}$, respectively, for the standard behavior and violent behavior. Thus, after identifying the behavior 
of the $\mathrm{CRW}$, the determination of the $\mathrm{CN}(\mathrm{P})$ values for each event (unordered) in $\mathrm{M} 2$ was performed by applying the equation corresponding to the behavior of the watershed.

$$
\begin{aligned}
& C N(P)=C N_{\infty}+\left(100-C N_{\infty}\right) \exp \left(-k_{1} R_{\text {total }}\right) \\
& C N(P)=C N_{\infty}\left[1-\exp \left(-k_{2} R_{\text {total }}\right)\right]
\end{aligned}
$$

Where: $\mathrm{CN}(\mathrm{P})$ is the $\mathrm{CN}$ value adjusted for $\mathrm{R}_{\text {total }}$; $\mathrm{CN}_{\infty}$ corresponds to the constant value of $\mathrm{CN}$ when $\mathrm{R}_{\text {total }}$ tends to infinity; $\mathrm{k}_{1}$ and $\mathrm{k}_{2}$ refer to coefficients adjusted by means of the leastsquares method.

\subsubsection{Two-CN System Model Approach Method (Soulis and Valiantzas 2012) - (M3)}

Soulis and Valiantzas (2012) proposed the Two-CN System Model Approach method, which aims to divide the watershed into two homogeneous areas characterized by relatively similar land uses. According to Walega et al. (2015), M3 is based on the hypothesis that, during a rainfall event, DSR is initially yielded in areas with less permeability, that is, with higher CN values. Thus, as the event continues, DSR also begins to occur in areas with greater permeability.

Therefore, two $\mathrm{CN}$ values are attributed to these areas for the application of $\mathrm{M} 3-\mathrm{CN}_{\mathrm{a}}$ and $\mathrm{CN}_{\mathrm{b}}$, in which $\mathrm{CN}_{\mathrm{a}}>\mathrm{CN}_{\mathrm{b}}$. If $\alpha$ represents the fraction of the watershed corresponding to $\mathrm{CN}_{\mathrm{a}}$, then $(1-\alpha)$ is the area represented by $\mathrm{CN}_{\mathrm{b}}$. The procedures recommended by Soulis and Valiantzas (2012) were performed to apply M3 as follows:

1) The values of $R_{\text {total }}$ and ER were independently classified in decreasing order, forming pairs of values of $\mathrm{R}_{\text {total }}$ and $\mathrm{ER}$ with equal return periods;

2) The $\mathrm{CN}$ values obtained by $\mathrm{M} 1$ for $\mathrm{CRW}$ were related to their respective areas of occurrence within the watershed and organized in a decreasing order to determine the $\mathrm{CN}_{\mathrm{a}}$, $\mathrm{CN}_{\mathrm{b}}$, and $\alpha$ parameters. Then, considering the highest values of $\mathrm{CN}$ related to their respective areas of occurrence, a weighted average $\mathrm{CN}$ was calculated, referring to the initial value of $\mathrm{CN}_{\mathrm{a}}$. Likewise, the weighted average $\mathrm{CN}$ value calculated for the areas of lower $\mathrm{CN}$ values corresponded to the initial value for $\mathrm{CN}_{\mathrm{b}}$.

3) For the initial $\mathrm{CN}_{\mathrm{a}}$ and $\mathrm{CN}_{\mathrm{b}}$ values, the values of $\mathrm{S}$ and $\mathrm{I}_{\mathrm{a}}$ were determined from Equations 2 and 3, respectively.

4) Equations 9, 10, and 11 were applied to calculate ER values, considering the observed $\mathrm{R}_{\text {total }}$ values. Subsequently, the $\mathrm{CN}$ values were calculated for each event using Equation 6.

5) Finally, the parameters $\mathrm{CN}_{\mathrm{a}}, \mathrm{CN}_{\mathrm{b}}$, and $\alpha$ were adjusted by using statistical optimization in an attempt to approximate the CN values calculated in Step 1 to those calculated in Step. The objective function used to optimize the parameters in CRW was the Root Mean Square Error (RMSE).

$$
E R_{a}=a\left[\frac{\left(R_{\text {total }}-\lambda\left(\frac{25400}{C N_{a}}-254\right)\right)^{2}}{R_{\text {total }}+(1-\lambda)\left(\frac{25400}{C N_{a}}-254\right)}\right]
$$




$$
\begin{aligned}
& E R_{b}=(1-a)\left[\frac{\left(R_{\text {total }}-\lambda\left(\frac{25400}{C N_{b}}-254\right)\right)^{2}}{R_{\text {total }}+(1-\lambda)\left(\frac{25400}{C N_{b}}-254\right)}\right] \\
& E R=\left\{\begin{array}{r}
\mathrm{ER}_{\mathrm{a}}, \lambda\left(\frac{25400}{\mathrm{CN}_{\mathrm{a}}}-254\right) \leq \mathrm{R}_{\text {total }} \leq \lambda\left(\frac{25400}{\mathrm{CN}_{\mathrm{b}}}-254\right) \\
\mathrm{ER}_{\mathrm{a}}+\mathrm{ER}_{\mathrm{b}}, \mathrm{R}_{\text {total }} \geq \lambda\left(\frac{25400}{\mathrm{CN}_{\mathrm{b}}}-254\right) \\
0, \mathrm{R}_{\text {total }} \leq \lambda\left(\frac{25400}{\mathrm{CN}_{\mathrm{a}}}-254\right)
\end{array}\right.
\end{aligned}
$$

\subsubsection{Heterogeneous CN Method (Soulis and Valiantzas, 2013) - (M4)}

This method is based on M3; however, M4 extends the number of CN categories to the actual number of combinations existing between soil classes and their land uses, i.e., the combinations obtained in M1, assuming that the DSR is the partial sum of $\mathrm{ER}_{\mathrm{i}}$ computed from these $\mathrm{CN}$ values. For the application of M4, Equations 12, 13 and 14 is rewritten (Soulis and Valiantzas 2013):

$$
\mathrm{CN}=\frac{25400}{\frac{R_{\text {total }}}{\lambda}+\left(\frac{(1-\lambda) \sum \mathrm{ER}_{\mathrm{i}}-\sqrt{(1-\lambda)^{2}\left(\sum \mathrm{ER}_{\mathrm{i}}\right)^{2}+4 \lambda \mathrm{P} \sum \mathrm{ER}_{\mathrm{i}}}}{2 \lambda^{2}}\right)+254}
$$

Where:

$$
\begin{aligned}
& E R_{i}=\left\{\begin{aligned}
0, & \mathrm{R}_{\text {total }}<\lambda\left(\frac{25400}{\mathrm{CNi}}-254\right) \\
\frac{\text { ai }}{100}\left[\frac{\left(\mathrm{R}_{\text {total }}-\lambda\left(\frac{25400}{\mathrm{CNi}}-254\right)\right)^{2}}{\mathrm{R}_{\mathrm{total}}+(1-\lambda)\left(\frac{25400}{\mathrm{CNi}}-254\right)}\right], & \mathrm{R}_{\text {total }} \geq \lambda\left(\frac{25400}{\mathrm{CNi}}-254\right)
\end{aligned}\right. \\
& \sum_{i=1}^{n} a i=100
\end{aligned}
$$

The following steps were performed (Soulis and Valiantzas, 2013) to obtain the $\mathrm{CN}_{\mathrm{i}}$ values for CRW:

1) The values of $R_{\text {total }}$ and ER were ordered as in $M 2$;

2) From Equation 6, the $\mathrm{CN}$ values were calculated for each pair formed by $\mathrm{R}_{\text {total }}$ and $\mathrm{ER}$;

3) The $\mathrm{CN}$ values obtained in M1 and their respective areas of occurrence within the CRW were used as initial values of the parameters $\mathrm{CN}_{\mathrm{i}}$ and $\mathrm{a}_{\mathrm{i}}$;

4) $E R_{i}$ values were calculated for each $R_{\text {total }}$ value considering the conditions described in Equation 13;

5) The $\mathrm{CN}$ values were calculated considering the $\mathrm{ER}_{\mathrm{i}}$ values, according to Equation 12;

6) The values of $\mathrm{CN}_{\mathrm{i}}$ and $\mathrm{a}_{\mathrm{i}}$ were readjusted through the optimization of Equation 12; seeking to approximate the values of CN calculated in Step 2 to those determined in Step 5. As in M3, RMSE was an objective function used for the optimization of the parameters.

\subsection{Selection and characterization of rainfall-runoff events}

A stage-discharge rating curve developed for the CRW's outlet was used to convert the 
water level data monitored at its outlet into streamflow values. The mean rainfall was calculated according to the Thiessen Polygons method (Thiessen and Alter, 1911). Thus, the observed hydrographs and the mean rainfall hyetographs in the CRW were determined for a 30-minute interval. This time interval is considered satisfactory for hydrological modeling in the CRW since it has an estimated time of concentration of 7.5 hours (Moura et al., 2021).

Forty rainfall-runoff events between 2015 and 2018 were selected, which were then represented by a hyetograph of mean rainfall and a hydrograph. The runoff separation was performed based on the hydrograph of each event by means of a graphical method, as described by Chow et al. (1988). Subsequently, the following characteristics of each event were determined: rainfall depth $\left(\mathrm{R}_{\text {total }}\right)$, 5-day antecedent rainfall depth $\left(\mathrm{R}_{5}\right)$, maximum rainfall intensity in 30 minutes $\left(I_{\text {máx }}\right)$, initial abstraction $\left(I_{a}\right)$, effective rainfall $(E R)$ and observed $C N$ $\left(\mathrm{CN}_{\mathrm{obs}}\right)$.

ER was obtained for each observed event using the SCS/CN model (NRCS, 1986), and $\mathrm{I}_{a}$ was defined as the total rainfall depth that occurred between the beginning of rainfall and the beginning of DSR, following the methodology described in Mishra and Singh (2006). $\mathrm{R}_{5}$ was computed based on the start date and time of each event.

\subsection{Statistical analysis}

The following evaluation criteria were used to verify the accuracy of the methods for definition of $\mathrm{CN}$ and, consequently, estimation of ER: relative error of each event (Re) (\%) (Equation 15), $\mathrm{P}_{\text {bias }}$ coefficient (\%) (Equation 16) and Nash-Sutcliffe coefficient (NS) (Nash and Sutcliffe, 1970) (Equation 17).

$$
\begin{aligned}
& \operatorname{Re}(\%)=\left(\frac{E s t_{i}-O b s_{i}}{O b s_{i}}\right) \cdot 100 \\
& \mathrm{P}_{\mathrm{bias}}(\%)=\left[\frac{\sum_{\mathrm{i}=1}^{\mathrm{n}}\left(\mathrm{Obs}_{\mathrm{i}}-\mathrm{Est}_{\mathrm{i}}\right)_{\mathrm{i}}}{\sum_{\mathrm{i}=1}^{\mathrm{n}}\left(\mathrm{Obs}_{\mathrm{i}}\right)_{\mathrm{i}}}\right] \cdot 100 \\
& \mathrm{NS}=1-\left[\frac{\sum_{\mathrm{i}=1}^{\mathrm{n}}\left(\mathrm{Obs}_{\mathrm{i}}-\mathrm{Est}_{\mathrm{i}}\right)_{\mathrm{i}}{ }^{2}}{\sum_{\mathrm{i}=1}^{\mathrm{n}}\left(\mathrm{Obs}_{\mathrm{i}}-\overline{\mathrm{Obs}}_{\mathrm{i}}\right)_{\mathrm{i}}{ }^{2}}\right]
\end{aligned}
$$

Where: Obsi represents the observed ER value for an event $i$, Est $_{i}$ refers to the estimated ER value for an event $\mathrm{i}$ and $\overline{\mathrm{Obs}}_{\mathrm{i}}$ is the average observed ER value.

\section{RESULTS AND DISCUSSION}

\subsection{Rainfall-runoff events}

The main characteristics of the rainfall-runoff events assessed in this study are presented in Table 2. Rainfall duration ranged from 3.5 to $63.0 \mathrm{~h}$, with an average value equal to $26.0 \mathrm{~h}$. On analyzing $\mathrm{R}_{\text {total }}$ and ER (Table 2 ), one can verify a noticeable variation in their values, which implies large variations in the $\mathrm{CN}_{\text {obs }}$ values.

\subsection{CN values obtained from M1, M2, M3, and M4 methods}

Twelve $\mathrm{CN}_{\text {II }}$ values, varying between 58 and 100, were determined when using M1 (Figure 2a), resulting in average values of 74, 55 and 87 for, respectively, $\mathrm{CN}_{\text {II }}, \mathrm{CN}_{\mathrm{I}}$ and $\mathrm{CN}_{\text {III. For }} \mathrm{M} 3$, the values found for the parameters $\mathrm{CN}_{\mathrm{a}}, \mathrm{CN}_{\mathrm{b}}$, and $\alpha$ were 87,25 , and 0.2814 , respectively (Figure $2 \mathrm{~b}$ ). In the case of $\mathrm{M} 4,7 \mathrm{CN}_{\mathrm{i}}$ values were derived. The values of $\mathrm{CN}$ and the area fractions of the CRW for M1, M3 and M4 are shown in Table 3. The spatial distribution of CN values obtained from M1, M3, and M4 is illustrated in Figure 2. Out of the three possible behaviors for M2, CRW fell within the standard behavior, as the calculated $\mathrm{CN}(\mathrm{P})$ values decreased as $R_{\text {total }}$ increased, tending to a constant value (Figure $2 d$ ). 
Table 2. Total rainfall depth $\left(\mathrm{R}_{\text {total }}\right)$, maximum rainfall intensity in 30 minutes ( $\left.\mathrm{I}_{\text {max }}\right)$, initial abstraction $\left(\mathrm{I}_{\mathrm{a}}\right)$, 5-day antecedent rainfall depth $\left(\mathrm{R}_{5}\right)$, antecedent moisture content (AMC), $\mathrm{CN}$ parameter, and effective rainfall (ER) for each rainfall-runoff event.

\begin{tabular}{|c|c|c|c|c|c|c|}
\hline Event & $\mathrm{R}_{\text {total }}(\mathrm{mm})$ & $\mathrm{I}_{\mathrm{a}}(\mathrm{mm})$ & $\mathrm{R}_{5}(\mathrm{~mm})$ & AMC & $\mathrm{CN}_{\mathrm{obs}}$ & $\mathrm{ER}(\mathrm{mm})$ \\
\hline 1 & 14.0 & 3.3 & 31.5 & I & 73 & 1.1 \\
\hline 2 & 19.0 & 4.4 & 40.8 & I & 64 & 1.3 \\
\hline 3 & 113.3 & 15.7 & 49.9 & II & 47 & 24.6 \\
\hline 4 & 32.0 & 14.7 & 7.3 & I & 63 & 1.8 \\
\hline 5 & 33.0 & 17.5 & 0.7 & I & 52 & 0.9 \\
\hline 6 & 50.7 & 6.2 & 0.0 & I & 36 & 4.0 \\
\hline 7 & 65.8 & 19.2 & 61.4 & II & 40 & 5.1 \\
\hline 8 & 53.1 & 22.2 & 62.2 & III & 55 & 4.0 \\
\hline 9 & 64.8 & 6.2 & 80.4 & III & 66 & 17.9 \\
\hline 10 & 37.3 & 8.5 & 41.1 & II & 76 & 7.5 \\
\hline 11 & 36.5 & 0.0 & 10.9 & I & 37 & 2.8 \\
\hline 12 & 18.4 & 3.2 & 46.8 & II & 81 & 3.0 \\
\hline 13 & 13.5 & 11.8 & 0.7 & I & 99 & 0.8 \\
\hline 14 & 40.6 & 1.2 & 0.8 & I & 28 & 2.2 \\
\hline 15 & 42.6 & 18.7 & 34.3 & I & 72 & 4.6 \\
\hline 16 & 71.5 & 33.4 & 3.1 & I & 28 & 2.1 \\
\hline 17 & 33.7 & 24.6 & 58.1 & III & 98 & 6.3 \\
\hline 18 & 132.7 & 26.7 & 13.4 & I & 43 & 25.5 \\
\hline 19 & 18.5 & 12.9 & 22.6 & I & 92 & 1.1 \\
\hline 20 & 41.7 & 15.2 & 40.1 & II & 65 & 4.3 \\
\hline 21 & 24.7 & 12.4 & 17.5 & I & 78 & 1.8 \\
\hline 22 & 102.9 & 11.1 & 33.8 & I & 49 & 23.7 \\
\hline 23 & 44.6 & 19.2 & 1.7 & I & 62 & 3.6 \\
\hline 24 & 101.6 & 27.2 & 21.7 & I & 40 & 12.0 \\
\hline 25 & 30.1 & 4.9 & 39.3 & II & 69 & 4.6 \\
\hline 26 & 23.2 & 18.2 & 4.5 & I & 95 & 1.5 \\
\hline 27 & 29.2 & 20.4 & 41.2 & II & 69 & 0.6 \\
\hline 28 & 32.1 & 13.5 & 69.6 & III & 57 & 1.6 \\
\hline 29 & 26.8 & 15.1 & 36.5 & II & 91 & 3.9 \\
\hline 30 & 47.3 & 24.2 & 17.4 & I & 42 & 1.4 \\
\hline 31 & 32.7 & 9.4 & 47.3 & II & 72 & 4.5 \\
\hline 32 & 97.4 & 37.6 & 0.7 & I & 47 & 10.3 \\
\hline 33 & 26.1 & 6.2 & 7.4 & I & 68 & 2.8 \\
\hline 34 & 54.6 & 6.3 & 30.7 & I & 60 & 10.8 \\
\hline 35 & 59.0 & 9.7 & 7.8 & I & 66 & 13.7 \\
\hline 36 & 42.5 & 7.3 & 0.2 & I & 41 & 3.1 \\
\hline 37 & 53.1 & 16.9 & 0.7 & I & 44 & 3.7 \\
\hline 38 & 65.6 & 20.7 & 1.9 & I & 65 & 11.2 \\
\hline 39 & 37.8 & 14.2 & 25.0 & I & 91 & 11.3 \\
\hline 40 & 40.5 & 10.6 & 39.1 & III & 84 & 11.6 \\
\hline
\end{tabular}


Table 3. $\mathrm{CN}$ values and corresponding area fractions obtained from M1, M3 and M4 for different soil and land-use classes.

\begin{tabular}{|c|c|c|c|c|c|c|c|}
\hline $\begin{array}{l}\text { Soil } \\
\text { classes }\end{array}$ & $\mathrm{HSG}^{*}$ & Land use classes & CN (M1) & $\mathrm{CN}$ (M3) & $\mathrm{CN}(\mathrm{M} 4)$ & Area $\left(\mathrm{km}^{2}\right)$ & $\begin{array}{c}\text { Area of } \\
\text { the watershed }(\%)\end{array}$ \\
\hline \multirow{5}{*}{$\begin{array}{l}\text { Yellow } \\
\text { Argisol }\end{array}$} & \multirow{5}{*}{$\mathrm{C}$} & Water body & 100 & 87 & 28 & 0.05 & 0.04 \\
\hline & & Bare soil & 87 & 87 & 92 & 19.4 & 16.0 \\
\hline & & Pasture & 83 & 87 & 92 & 11.7 & 9.6 \\
\hline & & Grassland & 71 & 87 & 92 & 31.2 & 25.8 \\
\hline & & Forest & 70 & 25 & 21 & 33.7 & 27.9 \\
\hline \multirow{5}{*}{$\begin{array}{l}\text { Grayish } \\
\text { Brown } \\
\text { Argisol }\end{array}$} & \multirow{5}{*}{$\mathrm{D}$} & Water body & 100 & 87 & 28 & 0.003 & 0.003 \\
\hline & & Bare soil & 90 & 87 & 92 & 1.7 & 1.4 \\
\hline & & Pasture & 87 & 87 & 92 & 0.8 & 0.7 \\
\hline & & Grassland & 78 & 87 & 92 & 3.1 & 2.6 \\
\hline & & Forest & 76 & 87 & 26 & 1.9 & 1.6 \\
\hline \multirow{5}{*}{$\begin{array}{c}\text { Red } \\
\text { Argisol }\end{array}$} & \multirow{5}{*}{ B } & Water body & 100 & 87 & 28 & 0.01 & 0.01 \\
\hline & & Bare soil & 80 & 87 & 92 & 3.4 & 2.8 \\
\hline & & Pasture & 75 & 87 & 13 & 2.2 & 1.8 \\
\hline & & Forest & 60 & 25 & 6 & 6.2 & 5.1 \\
\hline & & Grassland & 58 & 25 & 18 & 5.6 & 4.6 \\
\hline
\end{tabular}

*Hydrologic soil group.
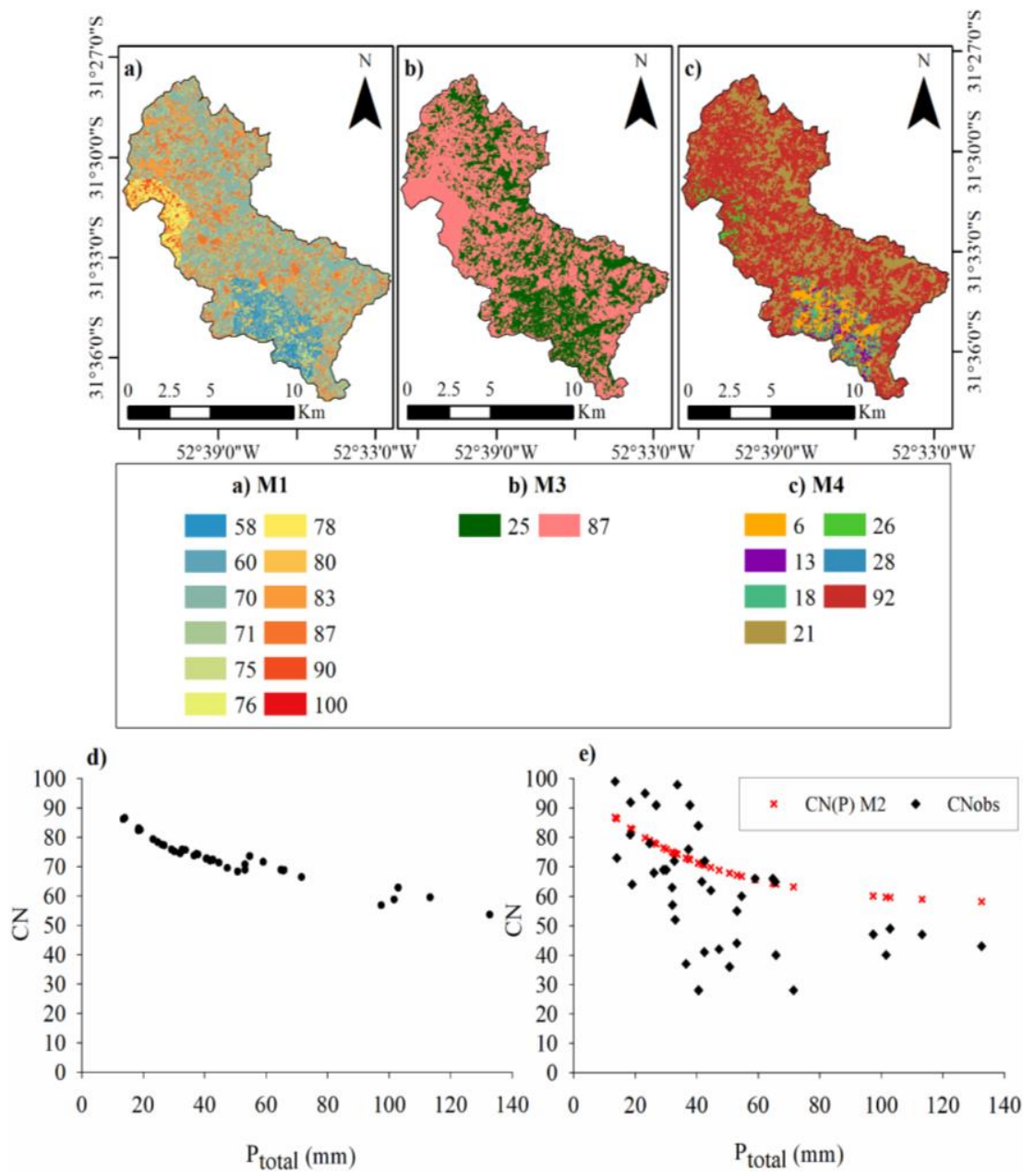

Figure 2. a) $\mathrm{CN}_{\mathrm{II}}$ values found for $\mathrm{M} 1, \mathrm{CN}$ values determined for b) $\mathrm{M} 3$ and c) M4, d) behavior of CRW with respect to M2, according to Hawkins 1993, and e) Asymptotic curve according to Hawkins (1993) in comparison with the $\mathrm{CN}_{\mathrm{obs}}$ values. \\ IPABH}


The parameters $\mathrm{CN}_{\infty}(57)$ and $\mathrm{k}_{1}(0.0251)$, of the equation used in $\mathrm{M} 2$ to compute $\mathrm{CN}$ as a function of $\mathrm{R}_{\text {total, }}$, were obtained considering the $40 \mathrm{R}_{\text {total }}$ :ER pairs (Equation 18). After using Equation 18 by applying the $\mathrm{R}_{\text {total }}$ value observed in each event (Figure $2 \mathrm{e}$ ), the estimated $\mathrm{CN}(\mathrm{P})$ values ranged between 59 and 88 .

$C N(P)=57+(100-57) \exp \left(-0,0251 \cdot R_{\text {total }}\right)$

Where: $\mathrm{CN}(\mathrm{P})$ is the $\mathrm{CN}$ value adjusted according to the $\mathrm{R}_{\text {total }}$.

The $\mathrm{CN}$ values determined from the methods applied in this study differed from the $\mathrm{CN}_{\mathrm{obs}}$ values. Some reasons for that must be highlighted: i) M1, M3, and M4 require information on soil classes and land uses to estimate the $\mathrm{CN}$ parameter, while $\mathrm{CN}_{\mathrm{obs}}$ is determined from observed rainfall-runoff data; ii) the characteristics of the watersheds used for the development

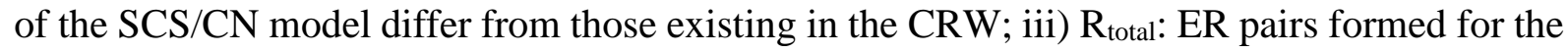
M2, M3 and M4 methods may not be representative for the reality of the events that occur in CRW; iv) it is difficult to identify the direct surface runoff in a watershed with such a large area, such as CRW, given the spatial and temporal variation of rainfall and other processes.

The low accuracy of M1 for determination of CN parameters in the CRW can be explained by the fact that the $\mathrm{CN}$ parameter does not depend only on the soil classes, land uses, and soil moisture, as recommended by M1. According to Kowalik and Walega (2015), the CN parameter is also affected by rainfall, which is not considered in M1. Besides, it is also expected to have lower performance when the watershed is treated as ungauged. Several studies that applied M1 to estimate the $\mathrm{CN}$ parameter in watersheds reported that its values obtained from the standard tables differed significantly from those empirically computed from observed data (Kowalik and Walega, 2015). In this sense, authors from different regions of the world have investigated and reported better estimates of $\mathrm{CN}$ values for watersheds using methods based on the calibration of observed data (D'Asaro et al., 2014; Ajmal and Kim, 2014; Alves et al., 2019).

\subsection{Performance analysis}

One can analyze in Table 4 the ER values estimated according to the SCS/CN Model considering the values of the $\mathrm{CN}$ parameter determined by M1, M2, M3, and M4, as well as the values of the precision statistics $\mathrm{Re}(\%), \mathrm{P}_{\text {bias }}$ and NS. The fitted data of ER and CN values observed and estimated following M1, M2, M3 and M4 can be analyzed in Figure 3.

Table 4. Minimum, average, median, and maximum effective rainfall values $(\mathrm{mm})$ obtained from the $\mathrm{CN}$ values estimated by the M1, M2, M3, and M4 methods and performance statistics.

\begin{tabular}{cccccc}
\hline & Observed & M1 & M2 & M3 & M4 \\
\hline Minimum & 0.6 & 0.0 & 1.0 & 0.2 & 0.6 \\
Average & 6.5 & 6.5 & 6.5 & 6.3 & 3.7 \\
Median & 3.9 & 0.8 & 3.7 & 4.2 & 3.1 \\
Maximum & 25.5 & 49.9 & 34.1 & 27.1 & 10.9 \\
\hline Re $(\%)$ & - & -100.0 to 582.9 & -68.3 to 380.8 & -77.0 to 431.9 & -73.2 to 261.4 \\
NS & - & -0.8 & 0.6 & 0.7 & 0.3 \\
$\mathrm{P}_{\text {bias }}(\%)$ & - & -0.4 & 0.0 & 2.3 & 41.9 \\
\hline
\end{tabular}




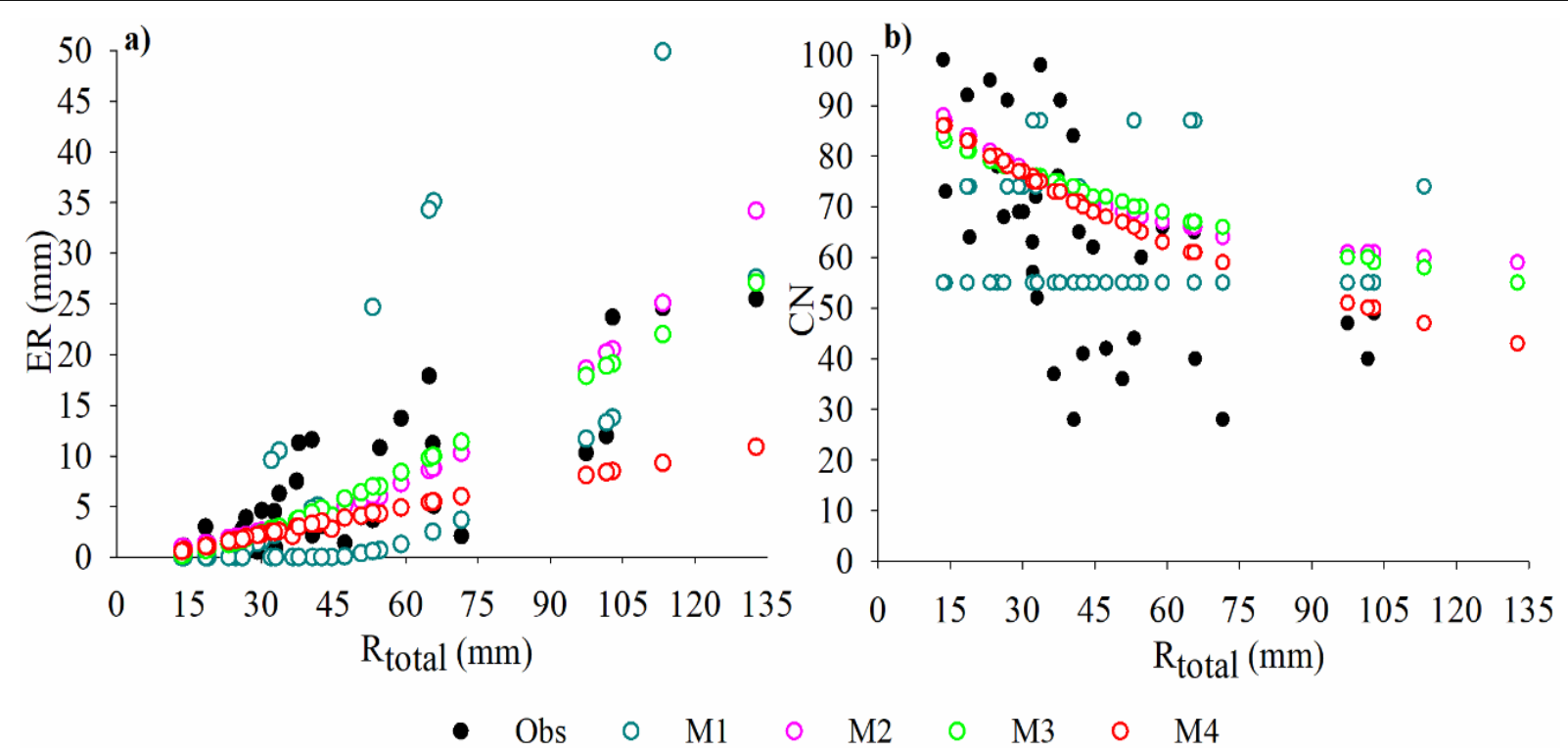

Figure 3. Plot of the rainfall depth of each event versus (a) the corresponding ER values derived from M1, M2, M3 and M4, and (b) the corresponding CN values determined from M1, M2, M3 and M4.

It can be inferred from Table 4 that M1 did not generate reliable results for ER in terms of performance statistics. $\mathrm{P}_{\text {bias }}$ indicated a tendency to overestimate ER values (-0.4\%) and the NS value (-0.8) reinforced the lack of accuracy of M1 for determining ER. The performance statistics for M2 indicated a better adjustment when compared to M1, given that $\mathrm{P}_{\text {bias }}$ and NS were equal to 0.0 and 0.6 , respectively. Analyzing the NS values of the methods to estimate ER, M3 outperformed the other methods $(\mathrm{NS}=0.7)$; however, the $\mathrm{P}_{\text {bias }}$ value indicated an underestimation of ER. The values of statistics in the estimation of ER according to M4 demonstrated that the method was not accurate, but this method resulted in a NS greater than that generated by M1, which presented the worst adjustment. On the other hand, analyzing the $\mathrm{P}_{\text {bias }}$ coefficient, M4 presented a high tendency of underestimations in the determination of ER, unlike the methods M1 and M2.

Based on the $R_{\text {total }}$ values obtained for each event, there was a relationship between the magnitude of the event and the percentage differences between the observed ER values and those estimated by M1. M1 tended to overestimate ER values for events with higher $\mathrm{R}_{\text {total }}$ values and underestimate ER with lower $\mathrm{R}_{\text {total }}$ values. A similar behavior occurred in the study by Cunha et al. (2015), where the authors explained that overestimations in ER values may be associated with the reduction in the $\mathrm{CN}_{\text {obs }}$ value as $\mathrm{R}_{\text {total }}$ value increases. On the other hand, underestimations in ER occur because most of the $R_{\text {total }}$ of the event is considered as part of $I_{a}$ values (Cunha et al., 2015). Another factor of influence in the underestimates was the classification of the AMC conditions, as 22 out of the 28 underestimated events were classified as AMC I, five events as AMC II, and only one event as AMC III. AMC I assumes that soil is very dry, resulting in high values of $\mathrm{I}_{\mathrm{a}}$ (Shaw and Walter, 2009).

The standard behavior observed in the events from CRW for M2 was similar to that found in the watershed analyzed by Hawkins (1993). In addition, the $\mathrm{CN}_{\infty}$ obtained for $\mathrm{M} 2$ was considerably different from the average $\mathrm{CN}$ obtained for M1. This difference observed for CRW may be due to the use of rainfall-runoff events from different rainfall regimes, that is, both convective rainfall and frontal rainfall. M2 produced results with better performances in estimating ER values when compared to M1. According to Alves et al. (2019), among the advantages of using an asymptotic approach to determine the $\mathrm{CN}$ parameter, it should be mentioned the fact that this method takes into account all events in the data set.

The parameters found for M3 in CRW indicate that the behavior of DSR in the watershed is more influenced by the characteristics of the rainfall, mainly by its intensity and duration. In 
this sense, even if the CRW has a larger area with permeable surfaces, Mishra and Singh (2006) underlines that higher rainfall intensities reduce the time water remains on the soil, thus resulting in a higher generation of DSR. In M3, the parameter $\alpha$ corresponds to $\mathrm{CN}_{\mathrm{a}}$ representing the portion of the watershed characterized by low permeability capacity (Walega et al., 2015); that is, where DSR is formed faster after the beginning of the rainfall. Therefore, analyzing the low calibrated value for $\alpha(0.2814)$ in M3 for CRW, one can infer that CRW has a larger area with permeable soils. According to Walega et al. (2015), the division of the watershed into two relatively homogeneous areas in M3 allows a very accurate estimate of the amount of ER. Walega et al. (2015) point out that, differently from M1 and M2, M3 considers the impact of spatial variability of the characteristics of the watershed.

The ER values obtained from M4 differed from those observed, mainly for events characterized by smaller $\mathrm{R}_{\text {total }}$. This behavior was also verified in the studies by Alves et al. (2019), Walega et al. (2015), and Ajmal and Kim (2014). According to Alves et al. (2019), M4 indicates that the ER generated in events with lower $\mathrm{R}_{\text {total }}$ is associated with areas of the watershed represented by higher $\mathrm{CN}$ values, i.e, in areas with greater difficulty of infiltration, such as urban areas, roads, and compacted soils. On the other hand, M4 did not perform well to estimate ER for events with greater magnitude, even though the $\mathrm{CN}$ values determined for M4 have been similar to the $\mathrm{CN}_{\text {obs }}$ values. This fact can be justified by the value of $\lambda$ considered (0.2), which implies very high $I_{a}$ values and less ER generation. In addition, the ER values calculated according to M4 have a direct impact on the use of the $\mathrm{CN}$ values resulting from $\mathrm{M} 1$ to calibrate its parameters.

Based on the ER values derived from M1, M2, M3 and M4, it can be observed that the results found corroborate those obtained by other authors. Walega et al. (2015) concluded in their study that M3 was more accurate when describing the observed ER values. Ajmal et al. (2015) observed that the $\mathrm{CN}$ values estimated from observed rainfall-runoff data provided better results than the values determined from standard tables of the SCS/CN model.

The results found in the ER estimate by the applied methods can be elucidated by the value used for $\lambda$. When analyzing different methods for estimating $\mathrm{CN}$, some authors found that the parameter $\lambda$ varied considerably depending on the watershed analyzed. Beskow et al. (2009) calibrated a value of $\lambda$ equal to 0.105 for a watershed located in the south of Minas Gerais State/Brazil. In the study by Caldeira et al. (2019), the calibration of the LASH hydrological model for the Fragata River Watershed, located near CRW, resulted in values of $\lambda$ of 0.147 (distributed modeling) and 0.039 (semi-distributed modeling). In this sense, it appears that it is not advisable to use the fixed value recommended by the SCS/CN Model for $\lambda$, since the variations in the value of the parameter $\lambda$ in the watersheds occur due to differences in climatic conditions, land use, and antecedent moisture content (Beskow et al., 2011).

It should be noted that the SCS/CN model considers rainfall events of short duration and, therefore, without significant variation in the maximum potential for water infiltration in the soil during the event. However, the events that occur in watersheds with predominance of frontal systems, such as CRW, are long-lasting and experience varying intensities over time (Beskow et al., 2018). Thus, the maximum potential for water infiltration in the soil may vary during the event, given the variability of losses by evapotranspiration and infiltration that significantly depend on the time that water remains on the soil surface (Mishra et al., 2008).

\section{CONCLUSIONS}

The different methods evaluated in this study for obtaining the $\mathrm{CN}$ parameter resulted in contrasting performances with respect to the estimation of ER for CRW. Based on the results obtained, the following conclusions can be drawn:

Rev. Ambient. Água vol. 16 n. 4, e2715 - Taubaté 2021 
- The $\mathrm{CN}$ values estimated derived from the four applied methods produced significant differences compared to the $\mathrm{CN}_{\text {obs }}$ values.

- M1 resulted in ER values with little reliability for CRW, mainly due to the classification of soil AMC classes, such that, in general, the events with $\mathrm{CN}$ values classified under AMC I resulted in underestimations of ER values for CRW.

- The $\mathrm{CN}$ values obtained from $\mathrm{M} 2$ were not close to the $\mathrm{CN}_{\mathrm{obs}}$ values since the hydrological reality of CRW does not present a good relationship between $\mathrm{R}_{\text {total }}$ and ER. In this sense, for watersheds with this behavior, it would be interesting to evaluate the influence of the temporal distribution of the rainfall event on the variation of $S$ for modeling ER.

- $\mathrm{M} 2$ and M3 provided the most accurate results in determining ER for CRW, with better performance for $\mathrm{M} 3$, which had $\mathrm{CN}_{\mathrm{a}}$ and $\mathrm{CN}_{\mathrm{b}}$ parameters with very clear physical meaning for this watershed.

\section{REFERENCES}

AJMAL, M.; KIM, T. W. Quantifying Excess Stormwater Using SCS-CN-Based Rainfall Runoff Models and Different Curve Number Determination Methods. Journal of Irrigation and Drainage Engineering, v. 141, n. 3, p. 1-12, 2014. https://doi.org/10.1061/(ASCE)IR.1943-4774.0000805

AJMAL, M.; WASEEM, M.; AHN, J. H.; KIM, T. W. Improved Runoff Estimation Using Event-Based Rainfall-Runoff Models. Water Resources Management, v. 29, p. 19952010, 2015. https://doi.org/10.1007/s11269-015-0924-z

ALVARES, C. A.; STAPE, J. L.; SENTELHAS, P. C.; GONÇALVES, J. L. M.; SPAROVEK, G. Koppen's climate classification map for Brazil. Meteorologische Zeitschrift, v. 22, n. 6, p. 711-728, 2014. https://dx.doi.org/10.1127/0941-2948/2013/0507

ALVES, G. J.; MELlO, C. R.; BESKOW, S.; JUNQUEIRA, J. A.; NEARING, M. A. Assessment of the Soil Conservation Service-Curve Number method performance in a tropical Oxisol watershed. Journal of Soil and Water Conservation, v. 74, n. 5, p. 500512, 2019. https://doi.org/10.2489/jswc.74.5.500

ASCE. Hydrology Handbook. 2. ed. New York, 1996. 784 p.

ARAÚJO NETO, J. R.; PALACIO, H. A. Q.; ANDRADE, E. M.; SANTOS, J. C. N.; PINHEIRO E. A. R. Otimização do Número de Curva (CN-SCS) para diferentes manejos na região semiárida, Ceará, Brasil. Revista Irriga, v. 1, n. 1, p. 264 - 279, 2012. https://doi.org/10.15809/irriga.2012v1n01p264

ARNOLD, J. G.; SRINIVASAN, R.; MUTTIAH, R. S.; WILLIAMS, J. R. Large area hydrologic modeling and assessment: part I: model development. Journal of the American Water Resources Association, v. 34, p. 73-89, 1998. https://doi.org/10.1111/j.1752-1688.1998.tb05961.x

BESKOW, S.; MELLO, C. R.; COELHO, G.; SILVA, A. M.; VIOLA, M. R. Estimativa do escoamento superficial em uma Bacia Hidrográfica com base em modelagem dinâmica e distribuída. Revista Brasileira de Ciência do Solo, v. 33, n. 1, p. 169-178, 2009. https://doi.org/10.1590/S0100-06832009000100018 
BESKOW, S.; MELLO, C. R.; NORTON, L. D.; SILVA, A. M. Performance of a distributed semi-conceptual hydrological model under tropical watershed conditions. Catena, v. 86, p. 160-171, 2011. https://doi.org/10.1016/j.catena.2011.03.010

BESKOW, S.; NUNES, G. S.; MELLO, C. R.; CALDEIRA, T. L.; NORTON, L. D.; STEINMETZ, A. A.; VARGAS, M. M., ÁVILA, L. F. Geomorphology-based unit hydrograph models for flood risk management: case study in Brazilian watersheds with contrasting physiographic characteristics. Anais da Academia Brasileira de Ciências, v. 90, n. 2, p. 1873-1890, 2018. https://doi.org/10.1590/0001-3765201820170430

CALDEIRA, T. L.; MELlO, C. R.; BESKOW, S.; TIMM, L. C.; VIOLA, M. R. LASH hydrological model: An analysis focused on spatial discretization. Catena, v. 173, p. 183193, 2019. https://doi.org/10.1016/j.catena.2018.10.009

CAO, H.; VERVOORT, W.; DABNEY, S. M. Variation in curve numbers derived from plot runoff data for New South Wales (Australia). Hydrological Processes, v. 25 n. 24, p. 3774-3789, 2011. https://doi.org/10.1002/hyp.8102

CHOW, V. T.; MAIDMENT, D. R.; MAYS, L. W. Applied Hydrology. New York: McGrawHill Book Company, 1988. 571 p.

CUNHA, N. G.; SILVEIRA, R. J. C.; SEVERO, C. R. S. Solos e terras do planalto Sul-RioGrandense e planícies costeiras. Pelotas: Embrapa Clima Temperado, 2006. 42 p.

CUNHA, S. F.; SILVA, F. E. O.; MOTA, T. U.; PINHEIRO, M. C. Avaliação da acurácia dos métodos do SCS para cálculo da precipitação efetiva e hidrogramas de cheia. Revista Brasileira de Recursos Hídricos, v. 20, n. 4, p. 837-848, 2015.

D'ASARO, F.; GRILLONE, G.; HAWKINS, R. H. Curve Number: Empirical Evaluation and Comparison with Curve Number Handbook Tables in Sicily. Journal of Hydrologic Engineering, v. 19, n. 12, 2014. https://doi.org/10.1061/(ASCE)HE.1943-5584.0000997

DESHMUKH, D. S.; CHAUBE, U. C.; EKUBE, A.; ABERRA, D.; TEGENE, M. Estimation and Comparison of Curve Numbers Based on Dynamic Land Use Land Cover Change, Observed Rainfall-Runoff Data and Land Slope. Journal of Hydrology, v. 492, p. 89 101, 2013. https://doi.org/10.1016/j.jhydrol.2013.04.001

ELHAKEEM, M.; PAPANICOLAOU, A. N. Estimation of the Runoff Curve Number via Direct Rainfall Simulator Measurements in the State of Iowa, USA. Water Resources Management, v. 23, n. 12, p. 2455-2473, 2009. https://doi.org/10.1007/s11269-0089390-1

ENDALE, D. M.; SCHOMBERG, H. H.; FISHER, D. S.; JENKINS, M. B. Curve Numbers from Conventional and No-Till Cropping: A 39-Year Dataset from a Small Georgia Piedmont Watershed. Transactions of the ASABE, v. 58, n. 2, p. 379-391, 2015. https://dx.doi.org/10.13031/trans.58.10892

HAWKINS, R. H. Asymptotic determination of runoff curve numbers from data. Journal of irrigation and drainage engineering, v. 119, p. 334-345, 1993. https://doi.org/10.1061/(ASCE)0733-9437(1993)119:2(334)

HUFFMAN, R. L.; FANGMEIER, D. D.; ELLIOT, W. J.; WORKMAN, S. R. Soil and Water Conservation Engineering. $6^{\text {th }}$ Edition. St. Joseph: ASABE, 2011, 523p.

Rev. Ambient. Água vol. 16 n. 4, e2715 - Taubaté 2021 
KOWALIK, T.; WALEGA, A. Estimation of CN Parameter for Small Agricultural Watersheds Using Asymptotic Functions. Water, v. 7, n. 12, p. 939-955, 2015. https://doi.org/10.3390/w7030939

KUPLICH, T. M.; CAPOANE, V.; COSTA, L. F. F. O avanço da soja no bioma Pampa. Boletim Geográfico do Rio Grande do Sul, n. 31, p. 83-100, 2018.

LAL, M.; MISHRA, S. K.; PANDEY, A. Physical verification of the effect of land features and antecedent moisture on runoff curve number. Catena, v. 133, p. 318-327, 2016. https://doi.org/10.1016/j.catena.2015.06.001

LUPATINI, M.; JACQUES, R. J. S.; ANTONIOLLI, Z. I.; SULEIMAN, A. K. A.; FULTHORPE, R. R.; ROESCH, L. F. W. Land-use change and soil type are drivers of fungal and archaeal communities in the Pampa biome. World Journal of Microbiology and Biotechnology, v. 29, n. 2, p. 223-233, 2013. https://doi.org/10.1007/s11274-0121174-3

MISHRA, S. K.; SINGH, V. P. A Relook at NEH-4 curve number data and antecedent moisture condition criteria. Hydrological Processes, v. 20, n. 13, p. 2755-2768, 2006. https://doi.org/10.1002/hyp.6066

MISHRA, S. K.; PANDEY, R. P.; JAIN, M. K.; SINGH, V. P. A Rain Duration and Modified AMC-dependent SCS-CN Procedure for Long Duration Rainfall-runoff Events. Water Resources Management, v. 22, p. 861-876, 2008. https://doi.org/10.1007/s11269-0079196-6

MOURA, M. M.; BESKOW, S.; TERRA, F. S.; MELLO, C. R, CUNHA, Z. A.; CASSALHO, F. Influence of different relief information sources on the geomorphological characterization of small watersheds. Anais da Academia Brasileira de Ciências, v. 93, e20191317, 2021. https://doi.org/10.1590/0001-3765202120191317

NASH, J. E.; SUTCLIFFE, J. V. River flow forecasting through conceptual models, Part I - A discussion of principles. Journal of Hydrology, v. 10, p. 282-290, 1970. https://doi.org/10.1016/0022-1694(70)90255-6

OLIVEIRA, P. T. S.; NEARING, M. A.; HAWKINS, R. H.; STONE, J. J.; RODRIGUES, D. B. B.; PANACHUKI, E. WENDLAND, E. Curve number estimation from Brazilian Cerrado rainfall and runoff data. Journal of Soil and Water Conservation, v. 71, n. 5, p. 420-429, 2016. https://doi.org/10.2489/jswc.71.5.420

OVERBECK, G. E.; MÜLlER, S. C.; FIDELIS, A.; PFADENHAUER, J.; PILLAR, V. D.; BLANCO, C. C. et al. Brazil's neglected biome: the South Brazilian Campos. Perspectives in Plant Ecology, Evolution and Systematics, v. 9, n. 2, p. 101-116, 2007. https://doi.org/10.1016/j.ppees.2007.07.005

PONCE, V. M.; HAWKINS, R. H. Runoff Curve Number: Has It Reached Maturity? Journal of Hydrologic Engineering, v. 1, n. 1, p. 11-19, 1996. https://doi.org/10.1061/(ASCE)1084-0699(1996)1:1(11)

SANTOS, H. G. dos. et al. Sistema Brasileiro de Classificação de Solos. 5. ed. Brasília, DF: Embrapa, 2018. 
SARTORI, A.; LOMBARDI NETO, F.; GENOVEZ, A. M. Classificação Hidrológica de Solos Brasileiros para a Estimativa da Chuva Excedente com o Método do Serviço de Conservação do Solo dos Estados Unidos Parte 1: Classificação. Revista Brasileira de Recursos Hídricos, v. 10, n. 4, p. 05-18, 2005.

SHAW, S. B.; WALTER, M. T. Improving runoff risk estimates: Formulating runoff as a bivariate process using the SCS curve number method. Water resources research, v. 45, 2009. https://doi.org/10.1029/2008WR006900

SOULIS, K. X. Estimation of SCS Curve Number variation following forest fires. Hydrological Sciences Journal, v. 63, n. 9, p. 1332-1346, 2018. https://doi.org/10.1080/02626667.2018.1501482

SOULIS, K. X.; VALIANTZAS, J. D. Variation of runoff curve number with rainfall in heterogeneous watersheds. The Two-CN system approach. Hydrology and Earth System Sciences, v. 16, n. 3, p. 1001-1015, 2012.

SOULIS, K. X.; VALIANTZAS, J. D. Identification of the SCS-CN Parameter Spatial Distribution Using Rainfall-Runoff Data in Heterogeneous Watersheds. Water Resources Management, v. 27, n. 6, p. 1737-1749, 2013. https://doi.org/10.1007/s11269-012-0082-5

STEINMETZ, A. A.; BESKOW, S.; TERRA, F. S.; NUNES, M. C. M.; VARGAS, M. M.; HORN, J. F. C. Spatial discretization influence on flood modeling using unit hydrograph theory. Revista Brasileira de Recursos Hídricos, v. 24, n. 16, 2019. https://doi.org/10.1590/2318-0331.241920180143

SOIL SURVEY STAFF. Keys to Soil Taxonomy. 12th ed. Washington DC.: USDA National Resources Conservation Services, 2014.

THIESSEN, A.; ALTER, J. C. Precipitation averages for large areas. Monthly Weather Review, v. 39, n. 7, p. 1082-1084, 1911. https://doi.org/10.1175/15200493(1911)39\%3C1082b:PAFLA\%3E2.0.CO;2

UNITED STATES. Natural Resources Conservation Service. National Engineering Handbook. Washington, 1986. (Technical Release, n. 55)

VALLE JUNIOR, L. C. G.; RODRIGUES, D. B. B.; OLIVEIRA, P. T. S. Initial abstraction ratio and Curve Number estimation using rainfall and runoff data from a tropical watershed. Revista Brasileira de Recursos Hídricos, v. 24, n. 5, 2019. https://doi.org/10.1590/2318-0331.241920170199

WALEGA, A.; MICHALEC, B.; CUPAK, A.; GRZEBINOGA, M. Comparison of SCS-CN Determination Methodologies in a Heterogeneous Catchment. Journal of Mountain Science, v. 12, n. 5, 2015. https://doi.org/10.1007/s11629-015-3592-9

ŽLÁBEK, P.; KAPLICKÁ, M.; KULHAVÝ, Z. Comparison Between Simulations of Significant Rainfall-runoff Events Generated by a SCS-CN-based Model and Measured Data in Three Subcatchments with Different Land Use. Littera Scripta, v. 5, n. 1, 2012. 